\title{
Kommentar
}

\section{En undervurdert halsbakterie}

De fleste halsinfeksjoner skyldes virus og er selvbegrensende, men særlig Epstein-Barr-virus kan gi uttalte symptomer ved mononukleose. Betahemolytiske streptokokker regnes som de mest aktuelle bakterielle agenser. Selv om den bakterielle munnhuleflora domineres av anaerobe bakterier, tillegges disse vanligvis liten betydning, annet enn ved abscesser og systemisk infeksjon utgående fra halsen. Fusobakterier tilhører denne anaerobe munn- og svelgflora. Fusobacterium necrophorum subspesies funduliforme er velkjent som årsak til Lemierres sykdom og peritonsillær abscess (1), men kanskje har bakteriens betydning ved lokal halsinfeksjon, faryngitt og tonsillitt så langt vært undervurdert.

Ved Lemierres syndrom gir F necrophorum invasiv sykdom med meget dramatisk sykdomsbilde, som beskrevet av Sarjomaa og medarbeidere i dette nummer av Tidsskriftet. Sykdommen er vanligst hos ungdommer og unge voksne. I Danmark er forekomsten anslått til minst 20 tilfeller i året (2), og med samme insidensrate skulle dette tilsvare over 17 tilfeller i Norge. I en dansk landsomfattende undersøkelse av lokalinfeksjon fant man bakterien hyppigst i prøver fra peritonsillære abscesser og tonsillitter, igjen som oftest hos ungdommer og unge voksne (3). Særlig synes pasienter med residiverende halsinfeksjoner å være disponert. Mye tyder på at $\mathrm{F}$ necrophorum kan ha kausal betydning ved tonsillitt, særlig ved residiverende infeksjoner hvor betahemolytiske streptokokker ikke kan påvises $(2,4)$. Ved residiverende tonsillitt kan det derfor være aktuelt å be om anaerob dyrking med tanke på F necrophorum.
Det er interessant at både mononukleose og halsinfeksjoner med F necrophorum hyppigst rammer ungdommer og unge voksne. Ved mononukleose kan både lymfeobstruksjon og immunologiske forhold berede veien for infeksjon med F necrophorum. Samtidig må man være oppmerksom på at falskt positiv Monospot er rapportert ved infeksjon forårsaket av $\mathrm{F}$ necrophorum (1).

Kanskje har det vært en økning av infeksjoner med F necrophorum siden 1980årene. Det har vært hevdet at dette kan skyldes redusert, kanskje noen ganger overforsiktig bruk av antibiotika i situasjoner der man ikke påviser betahemolytiske streptokokker (1). Dersom en bakteriell halsinfeksjon skal behandles, er penicillin førstevalget. Betahemolytiske streptokokker er alltid og F necrophorum som oftest følsom for penicillin. $\mathrm{F}$ necrophorum er ellers følsom for metronidazol, som bør være førstevalget ved påvist eller mistenkt etiologi med dette agens, eventuelt kombinert med penicillin ved blandet eller invasiv infeksjon utgående fra svelget (2). Klindamycin kan være et alternativ. Drenering av abscesser er ellers en viktig del av behandlingen.

Det foreligger en rekke rapporter om utvikling av infeksjon med F necrophorum etter forutgående behandling med erytromycin, et medikament som bakterien oftest er resistent overfor og som kan gi den en selektiv fordel. Det er interessant at i kasuistikken som er presentert i dette nummer av Tidsskriftet, hadde pasienten både mononukleose og var behandlet med erytromycin før innleggelsen.

Selv om Lemierres syndrom er sjelden, må klinikere tenke på denne diagnosen, spesielt hos alvorlig medtatte ungdommer og unge voksne med halsinfeksjon. Høy CRP, granulocytose og asymmetrisk hevelse på halsen bør lede til utredning av septiske metastaser og tromboflebitt i v. jugularis interna. Men også ved andre invasive og lokale residiverende halsinfeksjoner bør infeksjon med $\mathrm{F}$ necrophorum høre med i differensialdiagnosen.

\section{Arne Broch Brantsæter}

arne.brantsaeter@uus.no

Infeksjonsmedisinsk avdeling og NBC-senteret Oslo universitetssykehus, Ullevål

0407 Oslo

\section{Oppgitte interessekonflikter: Ingen}

\section{Litteratur}

1. Riordan T. Human infection with Fusobacterium necrophorum (Necrobacillosis), with a focus on Lemierre's syndrome. Clin Microbiol Rev 2007; 20 622-59.

2. Kristensen $\mathrm{LH}$, Jensen A, Prag J. Fusobacterium necrophorum: fra tonsilitis til Lemierres syndrom. Ugeskr Læger 2009; 171: 987-90.

3. Hagelskjaer KL, Prag J. Localised Fusobacterium necrophorum infections: a prospective laboratorybased Danish study. Eur J Clin Microbiol Infect Dis 2008; 27: 733-9.

4. Batty A, Wren MW, Gal M. Fusobacterium necrophorum as the cause of recurrent sore throat: comparison of isolates from persistent sore throat syndrome and Lemierre's disease. J Infect 2005: 51 : 299-306.

Manuskriptet ble mottatt 22.6. 2009 og godkjent 30.7. 2009. Medisinsk redaktør Odd Terje Brustugun. 